\title{
Five millennia of Bartonella quintana bacteraemia
}

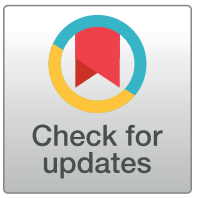

\section{G open access}

Citation: Mai B-H-A, Barbieri R, Chenal T, Castex D, Jonvel $R$, Tanasi $D$, et al. (2020) Five millennia of Bartonella quintana bacteraemia. PLoS ONE 15(11): e0239526. https://doi.org/10.1371/journal. pone. 0239526

Editor: David Caramelli, University of Florence, ITALY

Received: March 15, 2020

Accepted: September 9, 2020

Published: November 4, 2020

Peer Review History: PLOS recognizes the benefits of transparency in the peer review process; therefore, we enable the publication of all of the content of peer review and author responses alongside final, published articles. The editorial history of this article is available here: https://doi.org/10.1371/journal.pone.0239526

Copyright: ๑ 2020 Mai et al. This is an open access article distributed under the terms of the Creative Commons Attribution License, which permits unrestricted use, distribution, and reproduction in any medium, provided the original author and source are credited.

Data Availability Statement: All relevant data are within the paper and its Supporting Information files.

Funding: This study was supported by the French Government under the Investments for the Future

\section{Ba-Hoang-Anh Mai $\oplus^{1,2}$, Rémi Barbieri ${ }^{1}$, Thomas Chenal $^{3}$, Dominique Castex ${ }^{4}$, Richard Jonvel $\odot^{5}$, Davide Tanasi $\oplus^{6}$, Patrice Georges-Zimmermann ${ }^{7}$, Olivier Dutour ${ }^{8}$, David Peressinotto ${ }^{4,9}$, Coralie Demangeot ${ }^{4,9}$, Michel Drancourt ${ }^{1}$, Gérard Aboudharam ${ }^{1,10 *}$}

1 Aix-Marseille Université UM63, Institut de Recherche pour le Développement IRD 198, Assistance Publique-Hôpitaux de Marseille (AP-HM), Microbes, Evolution, Phylogeny and Infection (MEPHI), Institut Hospitalo-Universitaire (IHU)—Méditerranée Infection, Marseille, France, 2 Hue University of Medicine and Pharmacy, Hue, Vietnam, 3 CNRS, UMR 6298 ArTeHiS, France, 4 UMR 5199 du CNRS, PACEA, Anthropologie des Populations Passées et Présentes, Université de Bordeaux, Pessac, France, 5 Amiens Métropole Service Archéologie Préventive, France, 6 Department of History, University of South Florida, Tampa, Florida, United States of America, 7 INRAP, UMR 5608 CNRS, TRACES, France, 8 Ecole Pratique des Hautes Etudes, Université Paris Sciences Lettres-UMR 5199 CNRS, PACEA, Université de Bordeaux, Pessac, France, 9 HADES- Bureau d'investigation archéologiques, Bordeaux, France, 10 UFR Odontologie, Aix-Marseille Université, Marseille, France

* gerard.aboudharam@wanadoo.fr

\section{Abstract}

During the two World Wars, Bartonella quintana was responsible for trench fever and is now recognised as an agent of re-emerging infection. Many reports have indicated widespread B. quintana exposure since the 1990s. In order to evaluate its prevalence in ancient populations, we used real-time PCR to detect $B$. quintana DNA in 400 teeth collected from 145 individuals dating from the $1^{\text {st }}$ to $19^{\text {th }}$ centuries in nine archaeological sites, with the presence of negative controls. Fisher's exact test was used to compare the prevalence of $B$. quintana in civil and military populations. B. quintana DNA was confirmed in a total of $28 / 145$ (19.3\%) individuals, comprising 78 citizens and 67 soldiers, $20.1 \%$ and $17.9 \%$ of which were positive for $B$. quintana bacteraemia, respectively. This study analysed previous studies on these ancient samples and showed that the presence of $B$. quintana infection followed the course of time in human history; a total of 14/15 sites from five European countries had a positive prevalence. The positive rate in soldiers was higher than those of civilians, with $20 \%$ and $18.8 \%$, respectively, in the $18^{\text {th }}$ and $19^{\text {th }}$ centuries, but the difference in frequency was not significant. These results confirmed the role of dental pulp in diagnosing $B$. quintana bacteraemia in ancient populations and showed the incidence of $B$. quintana in both civilians and soldiers.

\section{Introduction}

In June 1915, a British military doctor on the western front of the First World War reported the first case of recurrent fever in a soldier who presented with a headache, dizziness, and severe pain in the lower back and leg. Additional cases with the same clinical features were 
program, managed by the Agence Nationale de la Recherche (ANR) (ref: Méditerranée Infection 10IAHU-03). This study was also supported by Région Le Sud (Provence Alpes Côte d'Azur) and European funding (FEDER BIOTK). The funders had no role in study design, data collection and analysis, decision to publish, or preparation of the manuscript.

Competing interests: The authors have declared that no competing interests exist. reported among soldiers in the trenches and it began to be referred to as "trench fever" [1]. The causative agent, Rickettsia quintana, was isolated from a patient in Mexico City by Vinson in 1961 and was reclassified in the genus Rochalimaea. In 1993, Rochalimaea merged with Bartonella $[2,3]$. The vector for transmission is the human body louse (Pediculus humanus corporis), the gastrointestinal tract of which is colonised by B. quintana. It is shed in lice faeces, and penetrates the human body through damaged skin, entering the bloodstream $[4,5]$. The typical cycle of fever occurred at five-day intervals (hence its other name, the "five-day fever"), resulting in prolonged disability so that affected soldiers were unfit for at least two months, many of them suffering from chronic fatigue [2]. Morbidity rates were not revealed by the authorities at the time, and no deaths were reported $[2,3]$. The clinical manifestations of $B$. quintana infection range from asymptomatic to a severe, life-threatening infection. These include, in addition to trench fever, lymphadenopathy, bacillary angiomatosis, and chronic bacteraemia and endocarditis $[5,6]$. In the absence of any appropriate treatment, the potential for relapse is due to the existence of an intraerythrocytic phase, as erythrocytes host bacteria during their life cycle [7]. Since the 1990s, B. quintana has been recognised as a re-emerging agent in homeless populations as a result of unsanitary living conditions [8-11].

The presence of trench fever can be traced back to the military in Europe before the First World War, when B. quintana DNA sequences were found in dental pulp from Napoleonic soldiers in Vilnius (1812) [12], and in bone from soldiers in Kassel (1813-814) [13]. Indeed, dental pulp with high vascularity has been the definitive key to diagnosing bacteraemia caused by microorganisms in paleomicrobiology [14]. Molecular biology has confirmed B. quintana bacteraemia occurred between 200 and 4,000 years ago, through the identification of B. quintana in dental pulp [15]. There has been no comprehensive study of the prevalence of the pathogen over the past two millennia in Europe. In order to perform such a study, we reviewed all paleomicrobiological data regarding B. quintana and combined this with the study of 400 additional specimens collected from 145 individuals over 20 centuries.

\section{Materials and methods}

\section{Ancient human samples}

Ancient teeth were collected from human remains in nine European burial sites by archaeologists and we were granted permission by the scientific managers of these sites to conduct microbiology studies. These samples are not restricted by any regulations in force and only require the authorisation of the scientific managers of these sites (all of whom have been acknowledged as co-authors) (S1 Text).

The specimen numbers used in this study are:

Besançon-France $\left(1^{\text {st }}-4^{\text {th }}\right)$ : Number from 1 to 29.

Catacombs of St. Lucia-Italy $\left(3^{\text {rd }}-6^{\text {th }}\right)$ : Number from 1 to 29.

San Basilio-Italy (4th- $\left.6^{\text {th }}\right)$ : Number from 1 to 8 .

Dueville-Italy $\left(6^{\text {th }}-7^{\text {th }}\right)$ : Number from 1 to 15 .

Remiremont-France (5th- $10^{\text {th }}$ ): Number from 1 to 45 .

Amiens-France $\left(18^{\text {th }}-19^{\text {th }}\right)$ : Number from 1 to 55 .

Dax-France (1792-1833): Number from 1 to 110.

Kaliningrad-Russia (1812): Number from 1 to 30.

Sevastopol- Ukraine (1853-1856): Number from 1 to 79. 
No permits were required for the described study and this study complied with all relevant regulations.

Following our current protocol for selecting and handling teeth, teeth were washed with sterile water and gradually dried, and the dental pulp was extracted using rotating disk instruments [16]. Total DNA was extracted using the phenol-chloroform protocol [17].

\section{Molecular detection}

Dental pulp was tested for B. quintana DNA using quantitative real-time PCR (qPCR) targeting the ITS gene using the following primers and probes: probe/6FAM-GCG CGC GCT TGA TAA GCG TG-TAMRA, forward/5' -GAT GCC GGG GAA GGT TT TC-3', reverse/5' GCC TGG GAG GAC TTG AAC CT-3' [18-20]. qPCR amplification was performed using the LightCycler $\AA 480$ Probes Master Kit according to the manufacturer's recommendations (Roche Diagnostics, Meylan, France). Each well contained $10 \mu \mathrm{L}$ of mix, $3 \mu \mathrm{L}$ of sterile water, $0.5 \mu \mathrm{L}$ of probe $(20 \mu \mathrm{M}), 0.5 \mu \mathrm{L}$ of each primer $(50 \mu \mathrm{M}), 0.5 \mu \mathrm{L} \mathrm{UDG}$, and $5 \mu \mathrm{L}$ of extracted DNA. Amplification consisted of a two-minute incubation step at $50^{\circ} \mathrm{C}$ and an initial fiveminute denaturation at $95^{\circ} \mathrm{C}$, followed by 40 cycles of denaturation at $95^{\circ} \mathrm{C}$ for five seconds and hybridisation at $60^{\circ} \mathrm{C}$ for 30 seconds. Two negative controls (control of DNA extraction + mix and sterile water + mix) were placed every five samples in each plate. A sample was considered positive when the qPCR result was positive with a cycle number $(\mathrm{Ct})$ lower than 40 .

\section{Fisher's exact test}

Fisher's exact test was used to compare the prevalence of B. quintana infection in the civilian population and military population, and a p-value $<0.05$ was considered statistically significant.

\section{Results}

A total of 400 ancient teeth from 145 individuals collected in nine European sites with different times of burial were analysed using qPCR. All negative controls were negative, and qPCR detected B. quintana DNA in all sites. The results indicated that a total of 78 civilians from six sites had $17.9 \%$ positivity, and 67 soldiers from three sites had $20.1 \%$ positivity. The positive detection at the Besançon site was the oldest, with data from the 1 st- $4^{\text {th }}$ centuries (Table 1 ). Seven of the 17 archaeological sites had data from the 18 th $-19^{\text {th }}$ centuries (Tables 1 and 2), where the prevalence of B. quintana DNA was 3/16 (18.8\%) among civilians and 24/120 (20\%) among soldiers; the difference in the prevalence was not significant (Table 3 ).

Table 1. Biomolecular results of B. quintana infection in ancient dental pulp.

\begin{tabular}{l|c|c|c|c|c|c|}
\hline \multicolumn{1}{c|}{ Sites } & Date & Positive teeth/total & Positive people/total & Number of teeth/person & Positive percentage & Population \\
\hline Besançon-France & $1^{\text {st }}-4^{\text {th }}$ & $7 / 29$ & $3 / 5$ & $4-7$ & $17.9 \%(14 / 78)$ \\
\hline Catacombs of St. Lucia-Italy & $3^{\text {rd }}-6^{\text {th }}$ & $1 / 29$ & $1 / 28$ & $1-2$ & $1-2$ \\
\hline San Basilio-Italy & $4^{\text {th }}-6^{\text {th }}$ & $1 / 8$ & $1 / 6$ & 1 & $3-8$ \\
\hline Dueville-Italy & $6^{\text {th }}-7^{\text {th }}$ & $2 / 15$ & $2 / 15$ & $3-4$ & $2-14$ \\
\hline Remiremont-France & $5^{\text {th }}-10^{\text {th }}$ & $13 / 45$ & $4 / 8$ & $20.1 \%(14 / 67)$ & \multirow{2}{*}{ Military } \\
\hline Amiens-France & $18^{\text {th }}-19^{\text {th }}$ & $4 / 55$ & $4 / 9$ & 1 & \\
\hline Dax-France & $1792-1833$ & $11 / 110$ & $2 / 30$ & $1-5$ & \\
\hline Kaliningrad-Russia & 1812 & $2 / 30$ & $8 / 28$ & & \\
\hline Sevastopol- Ukraine & $1853-1856$ & $14 / 79$ & & & \\
\hline
\end{tabular}

https://doi.org/10.1371/journal.pone.0239526.t001 
Table 2. Bartonella quintana detection in ancient specimens from previous studies.

\begin{tabular}{|c|c|c|c|c|c|c|c|}
\hline Sites & Date & Specimens & Methods & $\begin{array}{c}\text { Positive number of specimens/ } \\
\text { total }\end{array}$ & $\begin{array}{c}\begin{array}{c}\text { Positive number of people/ } \\
\text { total }\end{array} \\
\text { (a) }\end{array}$ & Population & Ref. \\
\hline $\begin{array}{l}\text { Peyraoutes- } \\
\text { France }\end{array}$ & 2000BCE & \multirow[t]{6}{*}{$\begin{array}{l}\text { Dental } \\
\text { pulp }\end{array}$} & \multirow[t]{2}{*}{$\begin{array}{l}\text { Suicide PCR (groEL, hbpE } \\
\text { genes) }\end{array}$} & $1 / 6$ & $1 / 3$ & \multirow[t]{2}{*}{-} & \multirow[t]{2}{*}{ [21] } \\
\hline Roaix-France & $\begin{array}{l}\text { 2200BCE- } \\
\text { 2100BCE }\end{array}$ & & & 0 & $0 / 3$ & & \\
\hline Bondy-France & $11^{\text {th }}-15^{\text {th }}$ & & \multirow[t]{3}{*}{ Real time PCR (ITS gene) } & $3 / 14$ & $3 / 5$ & Civilian & [18] \\
\hline Venice-Italy & $15^{\text {th }}-16^{\text {th }}$ & & & $5 / 173$ & - & Civilian & [19] \\
\hline Douai-France & $18^{\text {th }}$ & & & $1 / 40$ & - & Military & [20] \\
\hline \multirow[t]{2}{*}{$\begin{array}{l}\text { Vilnius- } \\
\text { Lithuania }\end{array}$} & \multirow[t]{2}{*}{1812} & & $\begin{array}{l}\text { Suicide PCR (hbpE, htrA } \\
\text { genes) }\end{array}$ & $7 / 72$ & $7 / 35$ & Military & \multirow[t]{2}{*}{ [12] } \\
\hline & & Lice & PCR standard (hbpE gene) & & & & \\
\hline Kassel -Germany & $1813-1814$ & Bone & PCR standard (hbpE gene) & $3 / 18$ & $3 / 18$ & Military & [13] \\
\hline Namur-Belgium & $14^{\text {th }}$ & Coprolite & Metagenomics & & & & [22] \\
\hline
\end{tabular}

(-): Not mentioned

https://doi.org/10.1371/journal.pone.0239526.t002

\section{Discussion}

The results reported here were authenticated by the fact that we chose ancient teeth, preferentially monoradicular teeth with a close apex, no traumatic lesions, and an absence of dental caries that helped minimise any risk of external contamination [16]. A positive control was not used in the PCR experiments because it could be a source of contamination; the negative controls remained negative [18]. To screen a total of 400 teeth, we used real-time PCR as previously described to identify B. quintana [18-20], and in this work, each experimental step was performed in different rooms of a new building, where these gene sequences had not previously been used. The number of teeth per individual was variable in each burial site due to availability, and we used as many teeth per individual as possible to increase the chance of detection. Indeed, the first report of using dental pulp for ancient septicaemia diagnosis indicated that the number of teeth per individual infected with Yersinia pestis was 1/4 teeth, 1/2 teeth, and $3 / 3$ teeth [14]. Furthermore, two teeth from one individual reported that the first was infected with Y.pestis and the second had co-infection of $Y$. pestis and B. quintana [18]. Accordingly, in several instances, co-detection of B. quintana with another deadly pathogen has been reported, such as Yersinia pestis, Rickettsia prowazekii, indicating that the detection of B. quintana does not preclude that of other pathogens in any archaeological site [12, 18, 23].

In 1915, the history of trench fever was marked by the report of new clinical features from soldiers involved in trench warfare [2,3]. In 2005, authentic evidence showed that B. quintana had caused bacteraemia in humans for more than 4,000 years, through analysis of DNA from dental pulp collected from Peyraoutes in France [21]. This pathogen was also later identified in this specimen from different burial sites, including Venice $\left(15^{\text {th }}-16^{\text {th }}\right.$ centuries) [19], Douai ( $18^{\text {th }}$ century) [20], Vilnius (1812) [12] and Bondy $\left(11^{\text {th }}-15^{\text {th }}\right.$ centuries) where an individual had coinfection with $Y$. pestis [18]. In addition to dental pulp, B. quintana was detected in

Table 3. Comparison of infected populations of $18^{\text {th }}-19^{\text {th }}$ centuries.

\begin{tabular}{l|c|c|c|c}
\hline \multicolumn{1}{c|}{ Population } & Total & Positive number & Percentage & p \\
\hline Civilians & 16 & 3 & $18.8 \%$ & $>0.05$ \\
\hline Soldiers & 120 & 24 & $20 \%$ & \\
\hline
\end{tabular}

https://doi.org/10.1371/journal.pone.0239526.t003 
ancient bone (1813-1814) [13] and coprolites (14th) century [22]. The bacterial confirmation in ancient pulp indicates that individuals had bacteraemia before their death, but it may not have been the cause of death, supporting the fact that no deaths have been recognised as being caused by trench fever $[2,5,24]$. A survey of 930 homeless people in Marseille revealed that $5.3 \%$ were blood culture positive for B. quintana [8], and asymptomatic chronic bacteraemia could be maintained for 78 weeks [25]. In 2004, B. quintana was found in the dental pulp of a homeless patient who had had bacteraemia in the previous six months [26].

Most of the reports of B. quintana in dental pulp come from our laboratory, with nearly half of burial sites being located in the $18^{\text {th }}-19^{\text {th }}$ centuries; $7 / 14$ sites were in France, 4/14 were in Italy, and the rest came from Ukraine, Russia, and Lithuania. This can be explained by the availability of samples in these periods, and the conditions in which our research team in France operate made it highly favourable to receiving these teeth from archaeological centres. The wide geographical and temporal distribution suggests that this bacterial infection was common in historic European populations. In the medical literature, the "five-day fever" and the Moldavia fever in the $19^{\text {th }}$ century had clinical signs similar to trench fever but laboratory techniques to confirm this were lacking at that time [27].

Millions of soldiers were contaminated around the world during the two World Wars. After the end of each war, however, incidence dropped dramatically but still sporadically persisted in some countries [5, 24]. It was noted that Napoleonic soldiers buried in Vilnius, Lithuania (1812) were exposed to body lice containing B. quintana, and approximately $20 \%$ and $8.6 \%$ of soldiers were infected with B. quintana and $R$. prowazekii, respectively [12]. An investigation of ancient bones from 18 soldiers from a mass grave inhumed in the winter of 1813-14 in Kassel, Germany, revealed that $16.7 \%$ of the soldiers had the infection [13]. In our study, only $6.7 \%$ of the soldiers from the Kaliningrad site tested positive, in contrast to the higher positive rates from Dax and Sevastopol. This can be explained by the use of only one tooth per individual for the Kaliningrad samples. The catacombs in St. Lucia, which represented the ancient Christian monument of the Late Roman period [28], had the similarity of also using one tooth, with the lowest positive proportion (3.6\%). During wartime, soldiers were generally crowded close together in unsanitary conditions for prolonged periods of time. Moreover, despite knowing the role that lice played in transmission and their presence in clothes, there were no effective methods of disinfection available $[2,3]$.

In order to ensure we were working with a uniform time period, we chose the $18^{\text {th }}-19^{\text {th }}$ centuries, which had a greater number of both populations. The incidence in civilians and soldiers was $18.8 \%$ and $20 \%$, respectively, and there was no significant difference. This suggests that this bacterial infection was relatively common throughout human society, without any detectable difference in lice infestation and clothing hygiene, although the sample size of citizens was small (18 citizens), which could affect the comparison. The epidemiology of trench fever involves interhuman transmission via vectors, such as body louse infection, or other transmission that may involve contact with reservoirs, insects bites [29], cat bites [30] or others that have yet to be defined and need further elucidation. Humans are not the only reservoirs of B. quintana; it is also found in cat fleas [31] and monkey fleas [32], and some studies have indicated other animals as known reservoirs through the detection of B. quintana in domestic cats [33], dogs [34], rhesus macaques [35, 36], and Japanese macaques [37]. Following an experimental study on cat fleas, it was shown that this pathogen was absorbed via the gastrointestinal tract and released into faeces [38]. Another study showed that the Pedicinus obtusus louse was postulated as an efficient vector of transmission between rhesus macaques [36]. Homelessness was defined as a high-risk factor for B. quintana infection as a consequence of inadequate hygiene $[8,10,11,25]$; however, some subpopulations have relatively high exposure rates, such as blood donors, with a rate of between $27 \%$ and $51 \%$ [9, 39, 40], and healthy people, with a 
rate of between $11.2 \%$ and $25 \%$ [ $40-43]$. There is no evidence to show that these people lived in unhygienic living conditions, such as being homeless, or that they had come into contact with body lice, suggesting the existence of some underestimated factors that cause a bacterial infection. The new findings on transmission, transmitted vectors, reservoirs, and widely infected populations contribute to the understanding of the infection from the past to the present; paleomicrobiological studies as this one helping to clarify complex host-pathogen interactions in past human populations, as previously reported $[44,45]$.

\section{Conclusions}

Dental pulp is conducive to the investigation of B. quintana bacteraemia in ancient populations, and it is relatively easy to collect and is well protected inside the tooth. Previous studies analysed in this study showed the presence of B. quintana infection 4,000 years ago and between the $1^{\text {st }}$ and $19^{\text {th }}$ centuries. Soldiers are considered the main target of this bacterial infection in human history, but in this study, we saw no significant difference between civilians and soldiers during the $18^{\text {th }}$ and $19^{\text {th }}$ centuries.

\section{Supporting information}

S1 Text. Nine European archeological sites.

(DOCX)

\section{Acknowledgments}

Our thanks go to Michael Decker (University of South Florida, Department of History, Tampa, Florida, USA) for his information on the samples. Thanks also go to the Pontifical Commission for Sacred Archaeology-Inspectorate for the Catacombs of Eastern Sicily for the permission to work on other samples from the Catacombs of Saint Lucia of Syracuse, Italy.

\section{Author Contributions}

Conceptualization: Michel Drancourt, Gérard Aboudharam.

Data curation: Ba-Hoang-Anh Mai, Rémi Barbieri, Michel Drancourt, Gérard Aboudharam.

Formal analysis: Ba-Hoang-Anh Mai.

Investigation: Ba-Hoang-Anh Mai, Michel Drancourt, Gérard Aboudharam.

Methodology: Michel Drancourt, Gérard Aboudharam.

Project administration: Michel Drancourt, Gérard Aboudharam.

Resources: Thomas Chenal, Dominique Castex, Richard Jonvel, Davide Tanasi, Patrice Georges-Zimmermann, Olivier Dutour, David Peressinotto, Coralie Demangeot, Michel Drancourt, Gérard Aboudharam.

Supervision: Michel Drancourt, Gérard Aboudharam.

Validation: Michel Drancourt, Gérard Aboudharam.

Writing - original draft: Ba-Hoang-Anh Mai, Rémi Barbieri, Thomas Chenal, Dominique Castex, Richard Jonvel, Davide Tanasi, Patrice Georges-Zimmermann, Olivier Dutour, Michel Drancourt, Gérard Aboudharam. 


\section{References}

1. Graham JHP. A note on a relapsing febrile illness of unknown origin. The Lancet. 1915; 186: 703-704. https://doi.org/10.1016/S0140-6736(01)53692-2

2. Anstead GM. The centenary of the discovery of trench fever, an emerging infectious disease of World War 1. Lancet Infect Dis. 2016; 16: e164-172. https://doi.org/10.1016/S1473-3099(16)30003-2 PMID: 27375211

3. Atenstaedt RL. Trench fever: the British medical response in the Great War. J R Soc Med. 2006; 99 : 564-568. https://doi.org/10.1258/jrsm.99.11.564 PMID: 17082300

4. Maurin M, Raoult D. Bartonella (Rochalimaea) quintana infections. Clin Microbiol Rev. 1996; 9: 273292. https://doi.org/10.1128/CMR.9.3.273-292.1996 PMID: 8809460

5. Foucault $C$, Brouqui $P$, Raoult D. Bartonella quintana Characteristics and Clinical Management. Emerg Infect Dis. 2006; 12: 217-223. https://doi.org/10.3201/eid1202.050874 PMID: 16494745

6. Drancourt M, Mainardi JL, Brouqui P, Vandenesch F, Carta A, Lehnert F, et al. Bartonella (Rochalimaea) quintana endocarditis in three homeless men. N Engl J Med. 1995; 332: 419-423. https://doi org/10.1056/NEJM199502163320702 PMID: 7529894

7. Angelakis $E$, Raoult $D$. Pathogenicity and treatment of Bartonella infections. Int J Antimicrob Agents. 2014; 44: 16-25. https://doi.org/10.1016/j.ijantimicag.2014.04.006 PMID: 24933445

8. Brouqui P, Stein A, Dupont HT, Gallian P, Badiaga S, Rolain JM, et al. Ectoparasitism and vector-borne diseases in 930 homeless people from Marseilles. Medicine (Baltimore). 2005; 84: 61-68. https://doi. org/10.1097/01.md.0000152373.07500.6e PMID: 15643300

9. Seki N, Sasaki T, Sawabe K, Sasaki T, Matsuoka M, Arakawa Y, et al. Epidemiological studies on Bartonella quintana infections among homeless people in Tokyo, Japan. Jpn J Infect Dis. 2006; 59: 31-35. PMID: 16495631

10. Brouqui $P$, Lascola $B$, Roux $V$, Raoult $D$. Chronic Bartonella quintana bacteremia in homeless patients. N Engl J Med. 1999; 340: 184-189. https://doi.org/10.1056/NEJM199901213400303 PMID: 9895398

11. Guibal F, de La Salmonière $P$, Rybojad M, Hadjrabia S, Dehen L, Arlet G. High seroprevalence to Bartonella quintana in homeless patients with cutaneous parasitic infestations in downtown Paris. J Am Acad Dermatol. 2001; 44: 219-223. https://doi.org/10.1067/mjd.2001.110062 PMID: 11174378

12. Raoult D, Dutour O, Houhamdi L, Jankauskas R, Fournier P-E, Ardagna $Y$, et al. Evidence for lousetransmitted diseases in soldiers of Napoleon's Grand Army in Vilnius. J Infect Dis. 2006; 193: 112-120. https://doi.org/10.1086/498534 PMID: 16323139

13. Grumbkow PV, Zipp A, Seidenberg V, Fehren-Schmitz L, Kempf VAJ, Gross U, et al. Brief communication: evidence of Bartonella quintana infections in skeletons of a historical mass grave in Kassel, Germany. Am J Phys Anthropol. 2011; 146: 134-137. https://doi.org/10.1002/ajpa.21551 PMID: 21710687

14. Drancourt M, Aboudharam G, Signoli M, Dutour O, Raoult D. Detection of 400 -year-old Yersinia pestis DNA in human dental pulp: an approach to the diagnosis of ancient septicemia. Proc Natl Acad Sci U S A. 1998; 95: 12637-12640. https://doi.org/10.1073/pnas.95.21.12637 PMID: 9770538

15. Fournier P-E, Drancourt M, Aboudharam G, Raoult D. Paleomicrobiology of Bartonella infections. Microbes Infect. 2015; 17: 879-883. https://doi.org/10.1016/j.micinf.2015.09.002 PMID: 26369716

16. Mai BHA, Drancourt M, Aboudharam G. Ancient dental pulp: Masterpiece tissue for paleomicrobiology. Mol Genet Genomic Med. 2020; e1202. https://doi.org/10.1002/mgg3.1202 PMID: 32233019

17. Barnett $R$, Larson $G$. A phenol-chloroform protocol for extracting DNA from ancient samples. Methods Mol Biol Clifton NJ. 2012; 840: 13-19. https://doi.org/10.1007/978-1-61779-516-9_2 PMID: 22237516

18. Tran T-N-N, Forestier CL, Drancourt M, Raoult D, Aboudharam G. Brief communication: co-detection of Bartonella quintana and Yersinia pestis in an 11th-15th burial site in Bondy, France. Am J Phys Anthropol. 2011; 145: 489-494. https://doi.org/10.1002/ajpa.21510 PMID: 21541920

19. Tran T-N-N, Signoli M, Fozzati L, Aboudharam G, Raoult D, Drancourt M. High throughput, multiplexed pathogen detection authenticates plague waves in medieval Venice, Italy. PloS One. 2011; 6: e16735. https://doi.org/10.1371/journal.pone.0016735 PMID: 21423736

20. Nguyen-Hieu T, Aboudharam G, Signoli M, Rigeade C, Drancourt M, Raoult D. Evidence of a louseborne outbreak involving typhus in Douai, 1710-1712 during the war of Spanish succession. PloS One. 2010; 5: e15405. https://doi.org/10.1371/journal.pone.0015405 PMID: 21060879

21. Drancourt $\mathrm{M}$, Tran-Hung L, Courtin J, Lumley H de, Raoult $\mathrm{D}$. Bartonella quintana in a 4000-year-old human tooth. J Infect Dis. 2005; 191: 607-611. https://doi.org/10.1086/427041 PMID: 15655785

22. Appelt S, Armougom F, Le Bailly M, Robert C, Drancourt M. Polyphasic analysis of a middle ages coprolite microbiota, Belgium. PloS One. 2014; 9: e88376. https://doi.org/10.1371/journal.pone.0088376 PMID: 24586319 
23. Nguyen-Hieu T, Aboudharam G, Signoli M, Rigeade C, Drancourt M, Raoult D. Evidence of a LouseBorne Outbreak Involving Typhus in Douai, 1710-1712 during the War of Spanish Succession. PLoS ONE. 2010; 5. https://doi.org/10.1371/journal.pone.0015405 PMID: 21060879

24. Ohl ME, Spach DH. Bartonella quintana and Urban Trench Fever. Clin Infect Dis. 2000; 31: 131-135. https://doi.org/10.1086/313890 PMID: 10913410

25. Foucault C, Barrau K, Brouqui $P$, Raoult D. Bartonella quintana Bacteremia among Homeless People. Clin Infect Dis Off Publ Infect Dis Soc Am. 2002; 35: 684-689. https://doi.org/10.1086/342065 PMID: 12203165

26. Aboudharam G, Fournier P-E, Drancourt M, Raoult D, Foucault C, Brouqui P. Molecular detection of Bartonella quintana DNA in the dental pulp of a homeless patient. Eur J Clin Microbiol Infect Dis Off Publ Eur Soc Clin Microbiol. 2004; 23: 920-922. https://doi.org/10.1007/s10096-004-1244-z PMID: 15558347

27. Hurst A. Medical diseases of War. Baltimore (MD): Williams and Wilkins. 1944.

28. Tanasi D. Nuove indagini archeologiche nella regione $C$ del cimitero di Santa Lucia a Siracusa, in Sgarlata M., Tanasi D. (eds.), Koimeis, Recent Excavations in the Siracusan and Maltese catacombs, Parnassos Press: Sioux City 2016, pp. 31-62. [cited 11 Mar 2020]. Available:

29. Bergmans AMC, Coenen JL, Bakhuizen R, Moot BW, Mister ARR, Wilbrink B, et al. Endocarditis in a Dutch patient caused by Bartonella quintana. Clin Microbiol Infect. 1997; 3: 692-695. https://doi.org/10. 1111/j.1469-0691.1997.tb00480.x PMID: 11864215

30. Breitschwerdt EB, Maggi RG, Sigmon B, Nicholson WL. Isolation of Bartonella quintana from a Woman and a Cat following Putative Bite Transmission. J Clin Microbiol. 2007; 45: 270-272. https://doi.org/10. 1128/JCM.01451-06 PMID: 17093037

31. Rolain J-M, Franc M, Davoust B, Raoult D. Molecular detection of Bartonella quintana, B. koehlerae, B. henselae, B. clarridgeiae, Rickettsia felis, and Wolbachia pipientis in cat fleas, France. Emerg Infect Dis. 2003; 9: 338-342. https://doi.org/10.3201/eid0903.020278 PMID: 12643829

32. Rolain J-M, Bourry O, Davoust B, Raoult D. Bartonella quintana and Rickettsia felis in Gabon. Emerg Infect Dis. 2005; 11: 1742-1744. https://doi.org/10.3201/eid1111.050861 PMID: 16318727

33. La VD, Tran-Hung L, Aboudharam G, Raoult D, Drancourt M. Bartonella quintana in Domestic Cat. Emerg Infect Dis. 2005; 11: 1287-1289. https://doi.org/10.3201/eid1108.050101 PMID: 16102321

34. Kelly P, Rolain J-M, Maggi R, Sontakke S, Keene B, Hunter S, et al. Bartonella quintana Endocarditis in Dogs. Emerg Infect Dis. 2006; 12: 1869-1872. https://doi.org/10.3201/eid1212.060724 PMID: 17326937

35. Huang R, Liu Q, Li G, Li D, Song X, Birtles RJ, et al. Bartonella quintana Infections in Captive Monkeys, China. Emerg Infect Dis. 2011; 17: 1707-1709. https://doi.org/10.3201/eid1709.110133 PMID: 21888799

36. Li H, Liu W, Zhang G-Z, Sun Z-Z, Bai J-Y, Jiang B-G, et al. Transmission and Maintenance Cycle of Bartonella quintana among Rhesus Macaques, China. Emerg Infect Dis. 2013; 19: 297-300. https://doi. org/10.3201/eid1902.120816 PMID: 23347418

37. Sato S, Kabeya H, Yoshino A, Sekine W, Suzuki K, Tamate HB, et al. Japanese Macaques (Macaca fuscata) as Natural Reservoir of Bartonella quintana. Emerg Infect Dis. 2015; 21: 2168-2170. https:// doi.org/10.3201/eid2112.150632 PMID: 26584238

38. Kernif T, Leulmi H, Socolovschi C, Berenger J-M, Lepidi H, Bitam I, et al. Acquisition and excretion of Bartonella quintana by the cat flea, Ctenocephalides felis. Mol Ecol. 2014; 23: 1204-1212. https://doi. org/10.1111/mec.12663 PMID: 24400877

39. Pitassi LHU, de Paiva Diniz PPV, Scorpio DG, Drummond MR, Lania BG, Barjas-Castro ML, et al. Bartonella spp. bacteremia in blood donors from Campinas, Brazil. PLoS Negl Trop Dis. 2015; 9: e0003467. https://doi.org/10.1371/journal.pntd.0003467 PMID: 25590435

40. Müller A, Reiter M, Schötta AM, Stockinger H, Stanek G. Detection of Bartonella spp. in Ixodes ricinus ticks and Bartonella seroprevalence in human populations. Ticks Tick-Borne Dis. 2016; 7: 763-767. https://doi.org/10.1016/j.ttbdis.2016.03.009 PMID: 26997137

41. Raoult D, Birtles RJ, Montoya M, Perez E, Tissot-Dupont H, Roux V, et al. Survey of three bacterial louse-associated diseases among rural Andean communities in Peru: prevalence of epidemic typhus, trench fever, and relapsing fever. Clin Infect Dis Off Publ Infect Dis Soc Am. 1999; 29: 434-436. https:// doi.org/10.1086/520229 PMID: 10476755

42. Costa PSG da, Brigatte ME, Greco DB. Antibodies to Rickettsia rickettsii, Rickettsia typhi, Coxiella burnetii, Bartonella henselae, Bartonella quintana, and Ehrlichia chaffeensis among healthy population in Minas Gerais, Brazil. Mem Inst Oswaldo Cruz. 2005; 100: 853-859. https://doi.org/10.1590/s007402762005000800006 PMID: 16444416 
43. Oteo JA, Maggi R, Portillo A, Bradley J, García-Álvarez L, San-Martín M, et al. Prevalence of Bartonella spp. by culture, PCR and serology, in veterinary personnel from Spain. Parasit Vectors. 2017; 10: 553. https://doi.org/10.1186/s13071-017-2483-z PMID: 29116007

44. Bos KI, Kühnert D, Herbig A, et al. Paleomicrobiology: Diagnosis and Evolution of Ancient Pathogens. Annu Rev Microbiol. 2019; 73:639-666. https://doi.org/10.1146/annurev-micro-090817-062436 PMID: 31283430

45. Rühli FJ, Galassi FM, Haeusler M. Palaeopathology: Current challenges and medical impact. Clin Anat. 2016; 29:816-822. https://doi.org/10.1002/ca.22709 PMID: 26940256 